\title{
Potential of some autochthonous wild plants of Burundi for vegetable oil and valuable compounds production
}

\author{
J. Niyukuria ${ }^{a, b *}$ (D), J. Raitia , S. El Qarnifa ${ }^{a}$, A. El Abbassi ${ }^{a}$ (D) and A. Hafidi ${ }^{a}$ \\ ${ }^{\mathrm{a} F o o d}$ Sciences Laboratory, Department of Biology, Faculty of Sciences Semlalia, Cadi Ayyad, University, P.O. Box 2390, \\ 40000, Marrakech, Morocco \\ ${ }^{b}$ Department of Environmental Sciences and Technologies, Faculty of Agronomy and Bioengineering, University of \\ Burundi, P.O. Box 2940, Bujumbura, Burundi \\ *e-mail: jonaniyu@gmail.com; niyukurijonathan@yahoo.fr
}

Received: May 3, 2019 - Accepted: July 15, 2019 - Distributed: November 30, 2020

(With 6 figures)

\begin{abstract}
Twelve species of indigenous plants have been studied in order to valorize some natural resources of Burundi (Eastern Africa) to investigate possibilities of vegetable oil production. Physicochemical properties and oil contents were determined from seeds harvested through five ecogeographic zones. From oilcake extracts, total sugars contents, proteins (TPrC), polyphenolic $(\mathrm{TPhC})$, and flavonoids were quantified using spectrophotometry. Furthermore, antioxidant activity of oilcake extracts was assessed by 2, 2-diphenyl-b-picrylhydrazyl (DPPH) radical-scavenging and ferric reducing antioxidant power (FRAP) assays. All oil contents obtained were found to be quite similar to those of common oleaginous seeds. The two highest were found in Parinari curatellifolia (61.44 $\pm 4.81 \%$ Dry Matter) and Myrianthus arboreus (48.26 $\pm 5.96 \%$ DM). More than half of the species have shown TPrC ranging from 10 to $24 \%$ dry matter of oilcake (DM). Brachystegia longifolia was revealed exceptionally stronger antioxidant potential: effectiveness antiradical of $163.06 \pm 26.29 \mathrm{~mL} / \mu \mathrm{g} \cdot \mathrm{min}$ (DPPH assay) and reducing power of $2618.21 \pm 161.22 \mathrm{GAE} / 100 \mathrm{~g}$ DM (FRAP assay). TPhC were positively correlated $(\mathrm{p}<0.05)$ to the antioxidant activity. This pioneering work on these wild species highlight the potential for producing vegetable oil and valuable biomolecule sources likely for food, cosmetics, pharmacy and industry.
\end{abstract}

Keywords: autochthonous species, oleaginous plants, oil content, polyphenols, antioxidant activity, Burundi.

\section{Potencial de algumas plantas silvestres autóctones do Burundi para a produção de óleos vegetais e compostos valiosos}

\section{Resumo}

Doze espécies de plantas indígenas foram estudadas para valorizar alguns recursos naturais do Burundi (África Oriental), para investigar as possibilidades de produção de óleo vegetal. As propriedades físico-químicas e o conteúdo de óleo foram determinados com base em sementes colhidas em cinco zonas ecogeográficas. A partir de extratos de bagaço de óleo, os teores de açúcares totais, proteínas (TPrC), polifenólicos (TPhC) e flavonoides foram quantificados por espectrofotometria. Além disso, a atividade antioxidante dos extratos de bagaços foi avaliada por ensaios de 2,2-difenil-b-picrilhidrazil (DPPH) e antioxidante redutor de ferro (FRAP). Todos os conteúdos de óleo obtidos foram encontrados para ser bastante semelhantes aos das sementes oleaginosas comuns. Os dois maiores foram encontrados em Parinari curatellifolia (61,44 $\pm 4,81 \%$ de matéria seca [MS]) e Myrianthus arboreus (48,26 $\pm 5,96 \%$ de MS). Mais da metade das espécies mostrou TPrC variando de $10 \%$ a $24 \%$ de MS de tortas. Brachystegia longifolia revelou um potencial antioxidante excepcionalmente mais forte: eficácia antirradical de 163,06 $\pm 26,29 \mathrm{~mL} / \mu \mathrm{g}$.min (DPPH assay) e poder redutor de 2.618,21 $\pm 161,22 \mathrm{GAE} / 100 \mathrm{~g}$ de MS (ensaio FRAP). TPhC correlacionaram-se positivamente $(\mathrm{p}<0,05)$ com a atividade antioxidante. Este trabalho pioneiro sobre essas espécies selvagens destaca o potencial para a produção de óleo vegetal e fontes valiosas de biomoléculas para alimentos, cosméticos, farmácia e indústria.

Palavras-chave: espécies autóctones, plantas oleaginosas, teor de óleo, polifenóis, atividade antioxidante, Burundi.

\section{Introduction}

The natural terrestrial ecosystems of Burundi provide great biological resource. The vascular flora already inventoried was estimated at 3125 species with 70 endemic
(MEEATU, 2013). Forest ecosystems constitute a source of plant material for domestication (Abbo and Gopher, 2017) increase food production and valuable substances 
isolation. The edible oil production from oleaginous plants cultivated in Burundi does not reach the national demand. The main oleaginous plant is oil palm (Elaeis guineensis). Although, it was introduced in Burundi before 1910 (Ngiye, 2017), its annual oil production (20000 tons) is still too low to reach the national demand which is estimated at 100000 tons/year (MINAGRIE, 2008). Unfortunately, intensification of oil palm cultivation leads to deforestation with all the harmful consequences that follow. It has been reported that the conversion of forest ecosystems to oil palm crops has severely impacted biodiversity in South Asia (Gaveau et al., 2009; Koh and Wilcove, 2008). Meanwhile, wild plants can provide valuable vegetable oils (Madzimure et al., 2011; Chan et al., 2013). Balanites aegyptiaca oils show interesting properties for food, pharmaceutical and industrial domain (Abasse et al., 2011), while that of Jatropha (Jatropha curcas) can be used for biodiesel production (Achten et al., 2008). The diversification of oleaginous plants would not only remedy the problem of the edible oil deficit, but would also provide various raw materials in different application domains (Merrien et al., 2012). Many other studies have shown that oilcakes still contain several valuable substances including fibers, proteins and polyphenols (Hussein, 2009; Merrien et al., 2012; Salgado et al., 2012; Chan et al., 2013). Nowadays, it is well known that phenolic compounds are powerful antioxidants and are therefore involved in different biological activities and in the prevention of many diseases (Aljadi and Kamaruddin, 2004; Amari et al., 2014; Brighenti et al., 2005; Shahidi and Ambigaipalan, 2015).

This preliminary study was carried out on Entada abyssinica Steudel ex A. Rich, Annona senegalensis Pers, Brachystegia longifolia Benth, Caesalpinia decapetala (Roth) Alston, Dodonaea viscosa Jacq, Ipomoea involucrata P. Beauv, Myrianthus arboreus Beauv., Maesopsis eminii Engl, Parinari curatellifolia Planch. Ex Benth, Sterculia tragacantha Lindl, Tephrosia vogelii Hook.f., Uvaria angolensis Welw. ex Oliv distributed in 9 families. These species are not yet cultivated but in a few rare cases, some feet of trees were deliberately left on the farm after clearing. They are all wild plants and grow naturally in the forest ecosystems. Their geographical distribution extends through all the savannas of eastern part of Burundi (Buragane, Kumoso and Buyogoma), and through all the vegetation formations that occupy the Congo-Nile ridge (Mumirwa, Bututsi and Mugamba). Locally, these plants are used as firewood, edible fruit, timber and traditional medicines (Supplementary Table 1). However, so far, no report on seed oils and bioactivity of oilcake from these seed species have been presented. The aim of this study was to valorize some wild autochthonous plants by determining their oil content, analyzing the qualitative parameters of the oils and by assessment of the antioxidant properties of oilcake extracts. This study highlights the potential production of oil and natural antioxidants of the country.

\section{Material and Methods}

\subsection{Plant material}

The fruits of E. abyssinica, A. senegalensis, B. longifolia, C. decapetala, D. viscosa, I. involucrata, M. arboreus, M. eminii, P. curatellifolia, S. tragacantha, T. vogelii, $U$. angolensis were sampled from May to December according to their period ripening. They were collected in five ecoclimatic zones, namely: the plain (775-1000 m of altitude), the foothills (1000-1500 m of altitude), the high mountains (1500-2600 m), the central trays (1400-2000 m of altitude) and the depressions (1200-1500 m of altitude) (Table 1). From the shapefile of the natural regions of Burundi, the calculated geometry automatically with arcMap 10.4.1 estimated that distribution occupy a surface of $15033 \mathrm{~km}^{2}$, more than half of the national territory. Species were harvested in three different sites according to the ecological conditions of each plant. The identification of the plant species was performed at the herbarium of the University of Burundi (BJA) and

Table 1. Seeds sampling.

\begin{tabular}{|c|c|c|c|c|c|c|c|}
\hline Plant species & Vernacular name & Sampling period & $\mathbf{P}$ & FH & HM & CT & $\mathbf{D}$ \\
\hline Entada abyssinica & umusange & July to October & & 1 & & 1 & 1 \\
\hline Annona senegalensis & Umukanda, Umutobe & October to November & & 1 & & 1 & 1 \\
\hline Brachystegia longifolia & Ingongo & October to November & 1 & 2 & & & \\
\hline Caesalpinia decapetala & Uruzira,Umubambangwe & July to October & & & 1 & 1 & 1 \\
\hline Dodonaea viscosa & umusasa & July to October & & & 1 & 1 & 1 \\
\hline Ipomoea involucrata & Umurandaranda & July to October & & 1 & 1 & & 1 \\
\hline Myrianthus arboreus & Umwufe & October to November & 2 & 1 & & & \\
\hline Maesopsis eminii & Umuhumura, Indunga & July to September & & 2 & & & 1 \\
\hline Parinari curatellifolia & Umunazi & August to October & & 1 & & 1 & 1 \\
\hline Sterculia tragacantha & Umutakataka & July to September & & 2 & & & 1 \\
\hline Tephrosia vogelii & Ntibuhunwa & June to August & & 1 & & 1 & 1 \\
\hline Uvaria angolensis & Umubungo & July to October & & 2 & & 1 & \\
\hline
\end{tabular}

$\mathrm{P}=$ Plain; $\mathrm{FH}=$ foothills of Mumirwa; $\mathrm{HM}=$ high mountains; $\mathrm{CT}=$ central trays; $\mathrm{D}=$ depressions; 1 = the species is sampled on the same site of an ecoclimatic zone; 2 = a species is sampled at two (communes) on the same ecoclimatic zone. 
the herbarium of the Burundian Office for the Protection of the Environment. Nine plants were sampled on each specie and three samples were collected per site. The ripe fruits, identifiable by their respective color, were harvested manually. After, the fruits were dried at room temperature in Microbiology Laboratory at University of Burundi. After drying, the seeds were hulled manually and then brought to Cadi Ayyad University (Morocco) in the Food Science Laboratory for further analysis.

\subsection{Oil content}

Seeds were crushed using a Moulinex blinder (France) and then the extraction was performed with hexane as solvent in Soxhlet apparatus under reflux for $8 \mathrm{~h}$. The solvent was evaporated under reduced pressure. Oil content was estimated gravimetrically by weighing the oil after complete removal of the solvent.

\subsubsection{Acidity and peroxide value determination}

The acidity was determined according to the method of ISO 660:2009 (ISO, 2009) norms and expressed in $g$ of oleic acid per $100 \mathrm{~g}$ of oil (g OA/100 g)

The peroxide value was analyzed according to the methodology described by ISO 3960:2007 (ISO, 2007) and it was expressed in milliequivalents of active oxygen $\left(\right.$ meq $\left.\mathrm{O}_{2}\right) / \mathrm{kg}$ of oil.

\subsubsection{Unsaponifiable matter preparation}

The extraction of the unsaponifiable material was carried out as described by ISO 18609:2000 (ISO, 2000) and it was expressed in $\mathrm{g}$ of extract/100 $\mathrm{g}$ of oil.

\subsection{Preparation of ethanol extracts from oilcake}

Ten grams of oilcake were mixed with ethanol $(80 \%)$ and homogenized for 30 minutes on a magnetic stirrer. The separation was done by centrifugation at $4000 \mathrm{rpm}$ for 20 minutes. The ethanol extract was recovered and the pellet was re-extracted for two times. The three obtained ethanol extracts were mixed and evaporated to dryness under reduced pressure (vacuum). The dry extract was recovered in $1 \mathrm{~mL}$ of $80 \%$ ethanol. Finally, yields were measured before storing the extracts at $-2{ }^{\circ} \mathrm{C}$ for further analysis.

\subsection{Determination of Total Sugar (TSC), Total Protein (TPrC), Total Polyphenols (TPhC), Total Flavonoids (TFC) content}

TSC was determined using (Dubois et al., 1956) method. The results were obtained by reference to a glucose standard range made under the same conditions as the samples and expressed as g glucose equivalent / $100 \mathrm{~g}$ dry matter of oilcakes (\% of DMOC).

The TPrC was estimated colorimetrically using the method of Bradford (1976). The results were expressed as mg Bovine Serum Albumin equivalent per $100 \mathrm{~g}$ dry matter of oilcakes (\% /of DMOC).

The TPhC of the samples was determined using Folin-Ciocalteau colorimetric method as described by (Slinkard and Singleton, 1977). The results were expressed as $\mathrm{mg}$ gallic acid equivalent per $100 \mathrm{~g}$ dry matter of oilcakes (mg GAE/100 g DMOC).

TFC was determined according to the aluminum chloride colorimetric method (Amezouar et al., 2013). The results were expressed as mg catechin (mg CE /1OO g DMOC).

\subsection{Antioxidant activity}

\subsubsection{DPPH radical scavenging activity assay}

Evaluation of the antioxidant activity of seeds extracts was performed using two approaches. Both the concentration of extract necessary to reduce $50 \%\left(\mathrm{IC}_{50}\right)$ of $\mathrm{DPPH}^{\cdot}$ after a duration of 60 minutes and the kinetics of reduction were determined. The DPPH free radical scavenging test was measured using the method described by (Lopes-Lutz et al., 2008) with some modifications. The principle of the method is based on the reduction of this radical which is accompanied by the turn of the violet color ( $\mathrm{DPPH} \bullet$ ) to yellow color measurable at $515 \mathrm{~nm}$. This reduction capacity is determined by a decrease in the absorbance induced by an antioxidant (Popovici et al., 2009). The concentration required to inhibit $50 \%$ of the DPPH (antiradical activity) was expressed as $\mathrm{IC}_{50}(\mathrm{mg} / \mathrm{mL})$. So, a lower $\mathrm{IC}_{50}$ value corresponds to a higher antioxidant activity (Patro et al., 2005). The kinetics of reaction and the parameters of calculation were determined using the method described by Sánchez-Moreno et al. (1998).

\subsubsection{Determination of the equilibrium time $T C_{50}$}

The parameter $\mathrm{TIC}_{50}$ is defined as the time needed to reach the equilibrium with an antioxidant concentration equal to $\mathrm{IC}_{50}$. This parameter is determined graphically.

\subsubsection{Determination of the Effectiveness Antiradical (EA)}

The two parameters $\mathrm{IC}_{50}$ and $\mathrm{TIC}_{50}$ can be combined to obtain the anti-free radical efficiency parameter: $\mathrm{EA}=\mathrm{TIC}_{50} / \mathrm{IC}_{50}$

\subsubsection{Ferric Reducing Antioxidant Power (FRAP) assay}

FRAP assay was measured according to method described by (Mouhoubi-Tafinine et al., 2016). The reducing agents in the extracts induce a reduction of ferric ions $(\mathrm{Fe}+3)$ to ferrous ions $(\mathrm{Fe}+2)$. This reduction is induced by a resulting intensity of the blue-green color. An increase in absorbance indicates that reducing power increases (Balasundram et al., 2006). Absorbance was measured using a spectrophotometer at a wavelength of $700 \mathrm{~nm}$. The results were expressed as gallic acid equivalents in $\mathrm{mg}$ per $100 \mathrm{~g}$ of product (mg GAE/100 g).

\subsection{Statistical analysis}

Data analysis was performed using IBM SPSS statistic 20. Results were analyzed using one-way analysis of variance (ANOVA) followed by Tukey's multiple comparison test. Correlation between various parameters was also investigated. Significance was determined at $p<0.05$ level and the results were expressed as mean values \pm standard error (SE). All tests were performed in triplicate. 


\section{Results and Discussion}

\subsection{Characterization of the lipid fraction}

\subsubsection{Oil content and chemical profile}

In this study, oil content of species studied varied significantly $(\mathrm{p}<0.05)$ from $8.15 \pm 0.32 \mathrm{DM}$ to $61.44 \% \pm 4.81 \mathrm{DM}$ (Figure 1). These results are similar to those reported in other seed oil commonly used as soybean (Song et al., 2017; Stahl et al., 1980), and canola seed (Thobani and Diosady, 1997). Similar contents were also recorded in unconventional oils such as Salvadora persica Linn. (Hussein, 2009) and cucumis melo var. agrestis (Mariod and Matthäus, 2007). Highest contents were observed in the P. curatellifolia $(61.44 \% \pm 4.81 \mathrm{DM})$, M. arboreus $(48.26 \% \pm 5.96 \mathrm{DM})$, and M. eminii $(46.58 \pm 6.82 \% \mathrm{DM})$. The lowest oil content was observed in B. longifolia $(8.15 \% \pm 0.32 \mathrm{DM})$. Although some oil contents seem very low, the potential interest in these oil can rise from their cosmetic properties and/or other properties. The corn oil content (5\%) (Portugal et al., 2017) is low than these all of our samples, however, it is widely used in pharmaceutical and cosmetic industries (Barrera-Arellano et al., 2019). The cactus with an oil content not exceeding 8.74\% (El Hachimi et al., 2015;

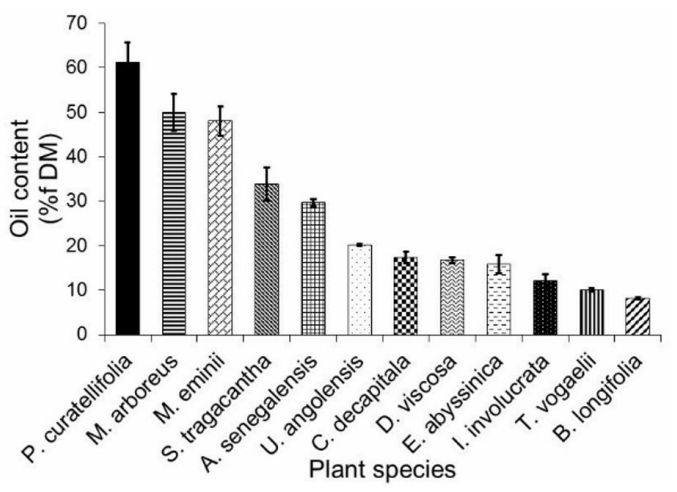

Figure 1. Oil content of the studied plants.
Ouhammou et al., 2017) is emerging due to its important antioxidant activity, $\alpha$-glucosidase inhibitory activity, cytotoxicity against human certain cancer cell lines, antimicrobial action, antifungal activity (Santiago et al., 2017).

Our results suggested that oil can be produced in all ecogeographical zones of Burundi (Table 1 and Figure 1). In the Imbo plain, only oil palm is produced, another species was found with an oil content of over $50 \%$. In the foothills of the Mumirwa escarpment, ten species were found with oil contents exceeding $16 \%$, among them six have more than $30 \%$. In the depressions, six species were found having an oil content exceeding $16 \%$, three of which exceeded $30 \%$. In the central trays, five species show an oil content that exceeds $16 \%$, two of them have more than $30 \%$. In the mountains, three species have oil contents exceeding $16 \%$, among them one species exceeds $30 \%$.

\subsubsection{Physicochemical properties}

Usually, vegetable oils contain more than 95\% triglycerides. Nevertheless, enzymatic hydrolysis intrinsic lipases contained in the seeds (Beisson et al., 2001) and some chemical reactions during oil extraction (Khattab and Zeitoun, 2013; Seneviratne and Dissanayake, 2015) can alter the composition. The quantification of the free fatty acids thus formed gives a good idea of the quality of the oil. Our results, Figure 2A show that the highest acidity observed, U. angolensis (7.81 g/100 g), was slightly higher than that fixed for a technologically accepted palm oil $(\leq 5 \mathrm{~g} / 100 \mathrm{~g})$ by $(\leq 5 \mathrm{~g} / 100 \mathrm{~g})$ by CODEX STAN 210-1999 norms (FAO, 2017). Low acidity levels were found in oils from P. curatellifolia $0.19 \pm 0.05 \mathrm{~g} \mathrm{OA} / 100 \mathrm{~g}$, E. abyssinica $0.55 \pm 0.01 \mathrm{~g} \mathrm{OA} / 100 \mathrm{~g}$, and $T$. vogaelii $0.73 \pm 0.03 \mathrm{~g} \mathrm{OA} / 100 \mathrm{~g}$. These values are comparable to those fixed by ISO 660:2009 (E) norms (ISO, 2009) on extra virgin olive oil $(\leq 0.343 \mathrm{~g} / 100 \mathrm{~g})$; on sunflower oil $(\leq 0.60 \mathrm{~g} / 100 \mathrm{~g})$ and on coconut oil $(\leq 0.830 \mathrm{~g} / 100 \mathrm{~g})$.

The Peroxide Value (PV) indicates the degree of primary oxidation of the oil. Internal factors such as the fatty acid composition, enzymes (Choe and Min, 2009; Doblado-Maldonado et al., 2012) and external factors like temperature (Sathivel et al., 2008) and oxygen
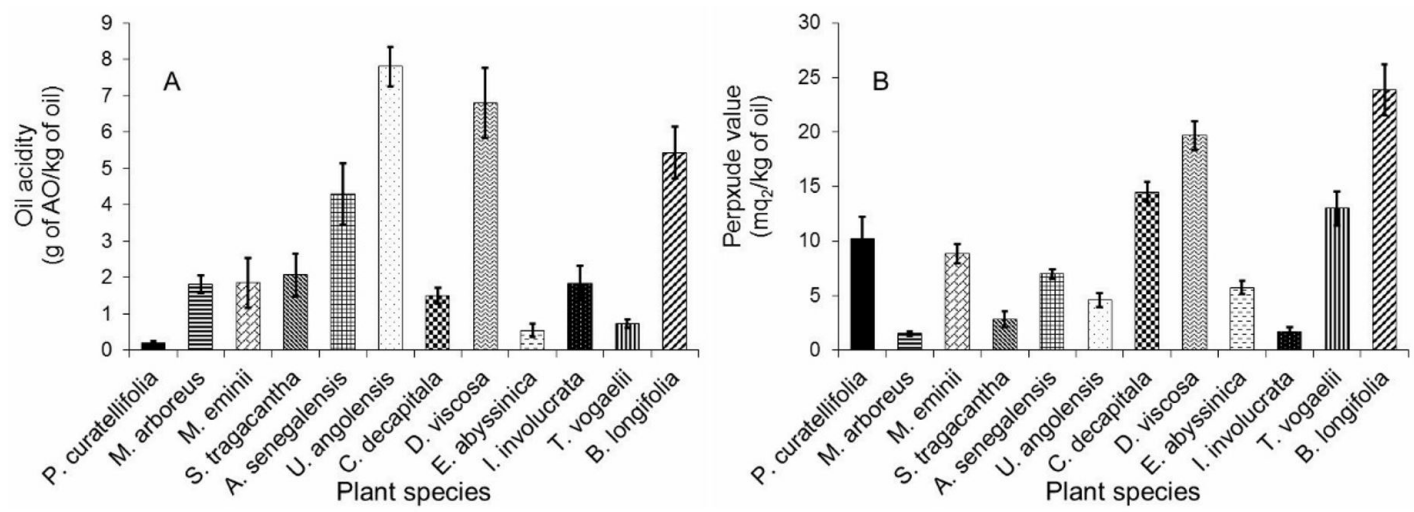

Figure 2. Acidity (A) and peroxide value (B) of the studied oils. $q_{2}$. 
partial pressure (Tan et al., 2002) were the main cause of oil oxidation. Deterioration of oil quality will lead to sensorial (rancidity) and lossing nutritional values (loss of polyunsaturated fatty acids and vitamin E) (Cuvelier and Maillard, 2012). In fact, the results of the oxidation state on our samples estimated by PVs are mentioned in Figure 2B. Except one sample, obtained PVs range from 1.51 to $19.66 \mathrm{~g}$ meq $\mathrm{O}_{2} / \mathrm{kg}$ and under the limit fixed by CODEX STAN 33-1981 norms (FAO, 2001a) on virgin olive oils ( $\leq 20$ meq $\left.\mathrm{O}_{2} / \mathrm{kg}\right)$. However, they were similar to those reported on cold pressed oil of

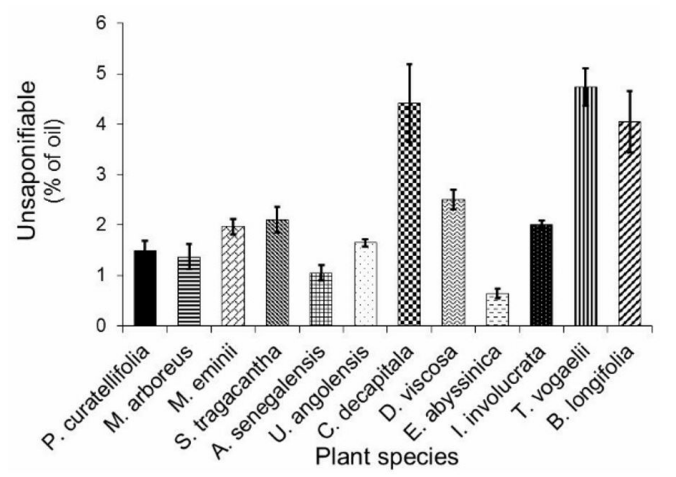

Figure 3. Unsaponifiable content of the studied oils.

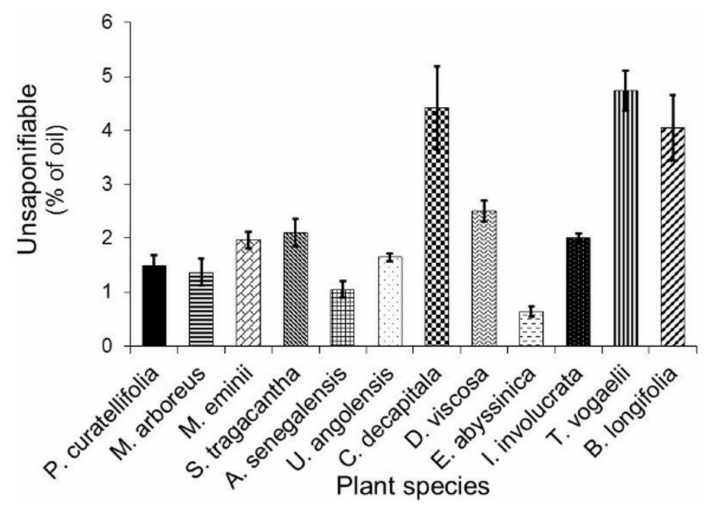

Figure 4. Ethanolic extracts from oilcakes.

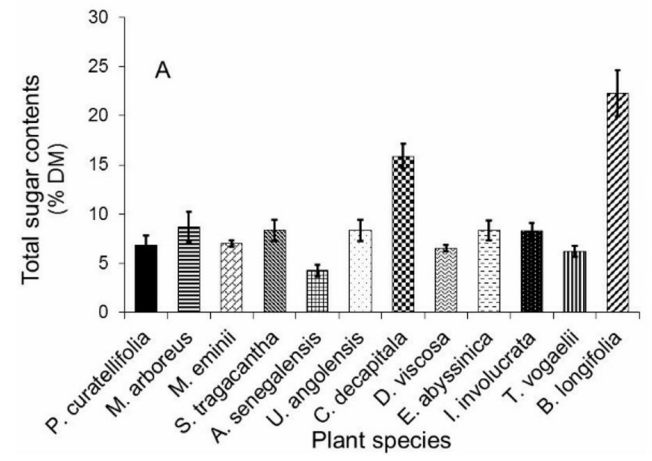

sunflower (4.19 meq $\left.\mathrm{O}_{2} / \mathrm{kg}\right)$, peanut (8.39 meq $\left.\mathrm{O}_{2} / \mathrm{kg}\right)$, rapeseed $\left(9.46 \mathrm{meq} \mathrm{O}_{2} / \mathrm{kg}\right)$, and olive $\left(6.39 \mathrm{meq} \mathrm{O}_{2} / \mathrm{kg}\right.$ ) (Bozdogan et al., 2018). Oil from B. longifolia was found to be more oxidized $\left(24.23 \pm 2.31 \mathrm{~g}\right.$ meq $\left.\mathrm{O}_{2} / \mathrm{kg}\right)$ but this parameter is greatly dependent on the quality of raw material and the processing parameter.

For most edible oils, Unsaponifiable material (USM) represent 0.5 to $2.5 \%$ of oil, with some exceptions, reaching 5 to $6 \%$ (Malecka, 1994). It contains hydrocarbons, terpene alcohols, sterols, tocopherols and other phenolic compounds (Boskou and Morton, 1976). Depending on its chemical constituents, it can contribute significantly to oxidative stability of oil (Chanioti and Tzia, 2017; Pazhouhanmehr et al., 2016). Our results on USM contents are presented in Figure 3. Thereby, USM contents found in seed oils from $E$. abyssinica $(0.63 \% \pm 0.10)$, A. senegalensis $(1.04 \% \pm 0.15)$ M. eminii $(1.3 \% 7 \pm 0.19)$, and P. curatellifolia $(1.49 \% \pm 0.25)$ were in agreement with the values fixed by CODEX STAN 210-1999 norms (FAO, 2001b) on virgin olive oil $(<1.5 \%)$, oil palm $(<12 \%)$, and soybean oil $(<1.5 \%)$. Furthermore, similar contents was reported on olive-pomace oils (2.52-4.38\%) (Chanioti and Tzia, 2017), and on rapeseed oil (0.26\%) (Schröder and Vetter, 2012).

\subsection{Characterization of oilcakes}

3.2.1. Extract yield, Total Tugars (TSC), Total Proteins (TPrC), Total Polyphenols (TPhC) and Total Flavonoids (TFC) contents

$\mathrm{TSC}, \mathrm{TPrC}, \mathrm{TPhC}, \mathrm{TFC}$ analyses were performed on extracts obtained with ethanol $80 \%$. Extract yields on oilcakes are depicted on Figure 4. It was found that the ethanolic extraction yields was exceeded $10 \%$ in all species. The highest extract content was observed in C. decapitala ( $24 \%$ dry matter of oilcake) while the lowest was for S. tragacantha $(10.24 \%)$. Most of the studied species has shown no significant difference $(p>0.05)$ between them.

The TSC from oilcakes determined using Dubois method and expressed as mg glucose equivalent are shown in Figure 5A. Based on Tukey's statistical test, the studied species are divided into two groups low sugar contents $(<10 \%)$ and a groups of high sugar contents $(>10 \%)$. Thus, Oilcakes of B. longifolia were found to have the highest TSC (22.23\%). It was followed by $C$. decapetala

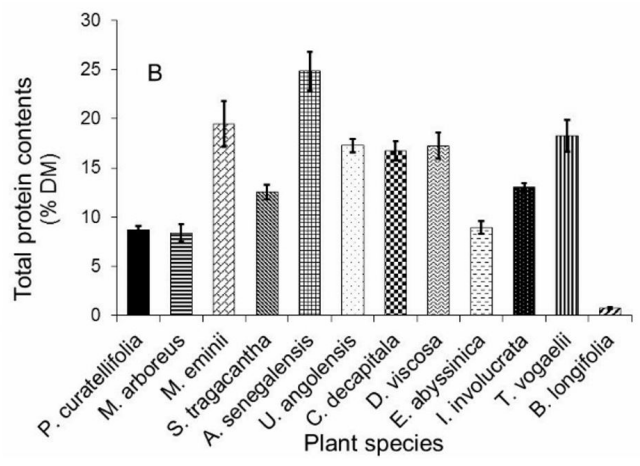

Figure 5. Total sugars content (A) and total proteins content (B). 
$(15.87 \%)$, the difference was found significant $(\mathrm{p}<0.05)$. A serie of 9 species showed TSC significantly different from the previous one $(\mathrm{p}<0.05)$, but not between them. Lowest TSCs were found in oilcakes of $A$. senegalensis (4.25\%) and T. vogaelii (6.21\%). This results revealed that species with high oil content were low in total sugar cotents (Table 1 and Figure 5A). Furthermore, a negative correlation $(\mathrm{p}<0.05)$ was observed between this two parameters (Table 2). This trend of the results is in accordance with the scientific literature. Lipids and sugars are both primary metabolites (Coutinho et al., 2018; Jia-xi et al., 2019) while sugars are also involved in lipid biosynthesis (Sun et al., 2018).

The results of the TPrC evaluation from oilcakes in different species studied are reported in Figure 5B. Using the Tukey test, six groups were found. The group of high $\operatorname{TPrC}(>20 \%)$ and that of low $\operatorname{TPrC}(<1 \%)$, each one, was constituted by single specie. All other species are regularly distributed between 7 and 20\% TPrC. Thus, 4 significantly different $(\mathrm{p}<0.05)$ groups were found. Each group consisted of 5 species of TPrC not significantly different $(p>0.05)$. However, overlaps were observed when one specie could belong to two groups. The highest TPrC were found in oilcake extracts of A. senegalensis $(24.82 \% \pm 3.18)$, M. eminii $(19.45 \% \pm 3.06)$, and T. vogelii $(18.27 \% \pm 1.48)$. B. longifolia oilcakes contained almost no protein. Its TPrC $(0.75 \%)$ was the lowest of the other species with a strong significant difference $(\mathrm{p}<0.05)$ compared to that of the penultimate (M. arboreus) which had $8.38 \%$. For most species, TPrCs allow them to be used as feed in livestock. Our results were found to be lower than those of soybean oilcake $(48,26)$ (Février et al., 1952) and sunflower oilcake $(31,7 \%)$ (Salgado et al., 2012) but comparable to those of cottonseed oilcake (16\%) (Zotte et al., 2013), Palm kernel cake (22.9\%) (Ribeiro et al., 2018) rapeseed oilcake (24.76\%) (Nájera et al., 2017). The confrontation between the data of Figure 1 and 5B made it possible to reveal many proteaginous seeds. The species that can supply both oil and protein at relatively high levels were $A$. senegalensis, M. emnii, U. angolensis, C. decapitala, and D. viscosa.
Polyphenols are secondary metabolites found in all plants. Nevertheless, their contents vary widely depending on the species, and the environmental factors (Connor et al., 2002; Ksouri et al., 2008). As shown in Figure 6A, the results obtained on TPhCs were characterized by a high variability. The three highest $\mathrm{TPhCs}$ were found in extracts of $B$. longifolia, T. Voegeli, and $M$. emnii $(1029.77 \pm 152.78>745.10 \pm 84.41>486.72 \pm 12.0 \mathrm{mg}$ $\mathrm{GAE} / 100 \mathrm{~g}$, respectively). The differences in TPhCs were found significant of $p<0.05$. Next highest contents were in group of six species whose TPhCs ranged, without significant difference ( $p>0.05$ ), from 200 to $350 \mathrm{mg} \mathrm{GAE} / 100 \mathrm{~g}$. Lowest recorded $\mathrm{TPhC}$ was found in $P$. curatellifolia oilcake ( $84.81 \pm 5.72 \mathrm{mg} \mathrm{GAE} / 100 \mathrm{~g})$. Phenolic contents are reported to widely vary among the plant species even in the same specie (Hatamnia et al., 2014), and depending on several factors physiological and environmental (Rabeta and Nur Faraniza, 2013). Our results were similar to those found on defatted kenaf seed meal $(339.93 \mathrm{mg}$ GAE $100 \mathrm{~g}$ defatted material) (Chan et al., 2013) and on

Table 2. Antioxidant activity of seed oilcake extracts with FRAP assay.

\begin{tabular}{lc}
\hline \multicolumn{1}{c}{ Plant species } & mg GAE /100 g \\
\hline P. curatellifolia & $16.13 \pm 1.44^{\mathrm{b}}$ \\
M. arboreus & $115.31 \pm 4.06^{\mathrm{b}}$ \\
M. eminii & $24.47 \pm 27.99^{\mathrm{b}}$ \\
S. tragacantha & $16.81 \pm 4.57^{\mathrm{b}}$ \\
A.senegalensis & $110.31 \pm 6.90^{\mathrm{b}}$ \\
U. angolensis & $55.50 \pm 4.51^{\mathrm{b}}$ \\
C.decapitala & $87.06 \pm 6.22^{\mathrm{b}}$ \\
D. viscosa & $37.08 \pm 5.84^{\mathrm{b}}$ \\
E. abyssinica & $78.33 \pm 6.98^{\mathrm{b}}$ \\
I. involucrata & $15.75 \pm 2.91^{\mathrm{b}}$ \\
T. vogaelii & $43.29 \pm 10.91^{\mathrm{b}}$ \\
B. longifolia & $2618.21 \pm 161.22^{\mathrm{a}}$ \\
\hline
\end{tabular}

Results are mean of three replicates with standard errors (Means \pm S.E, $n=3$ ). In each column, values with different letters mean that are significantly different $(p<0.05)$.
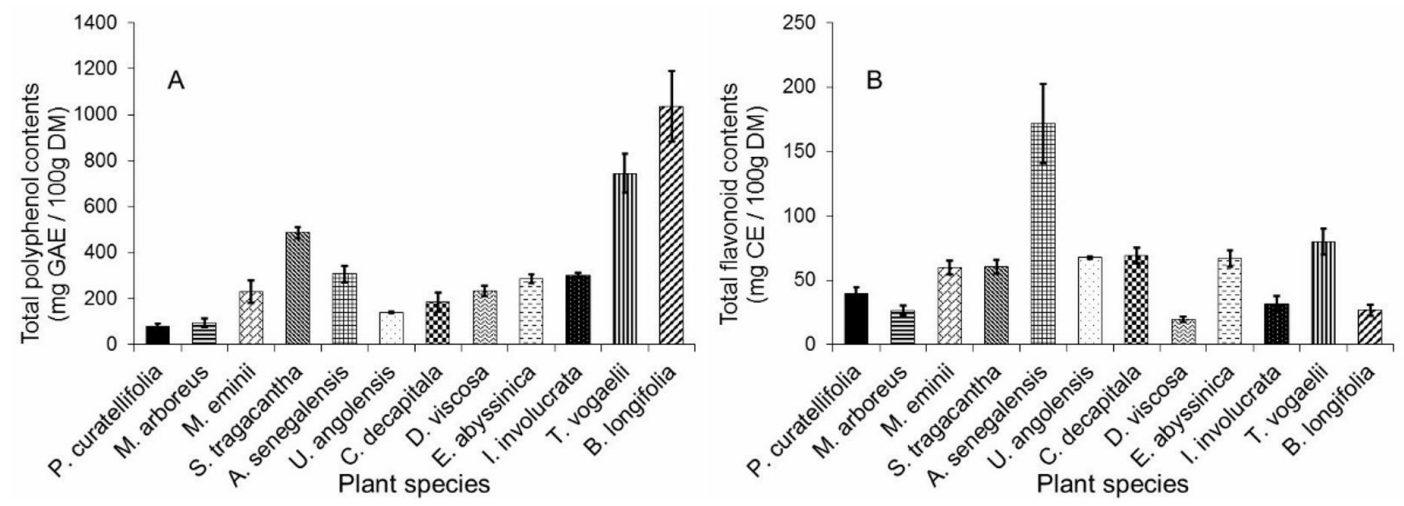

Figure 6. Total phenols content (A) and total flavonoids content (B) of oilcakes. 
Cynometra cauliflora fruit $(847.31+26.82 \mathrm{mg} \mathrm{GAE} / 100 \mathrm{~g}$ dried sample) (Rabeta and Nur Faraniza, 2013). Many of them are suggested to be a source of polyphenols. Flavonoids are the most abundant polyphenolic compounds found in plants (Ghasemzadeh and Ghasemzadeh, 2011; Jin et al., 2012). Due to their high bioactivity, they play an important role in human health and disease prevention (Kulkarni et al., 2016). TFC analysis from the twelve studied oilcake species, Figure $6 \mathrm{~B}$, revealed that all TFCs ranged from 20 to $80 \mathrm{mg} \mathrm{CE} / 100 \mathrm{~g}$ ) excepting the TFC obtained from A. senegalensis $(171.80 \pm 30.76 \mathrm{mg} \mathrm{CE} / 100 \mathrm{~g})$ which significantly exceeded the range $(\mathrm{p}<0.05)$. Nevertheless, considering the TFC / TPhC ratio (Figure $6 \mathrm{~B}, \mathrm{~A}$ ), only $B$. longifolia and D. viscosa were found to have proportions of $2 \%$ and respectively $9 \%$. For all other species, proportions were greater than $10 \%$, among them, highest were $57 \%$, $49 \%$ and $41 \%$ for $A$. senegalensis, $U$. angolensis and $P$. curatelifolia respectively.

\subsubsection{Antioxidant activities}

\subsubsection{DPPH radical scavenging assay}

DPPH assay was used to evaluate the antioxidant capacity of oilcake extracts in comparison to ascorbic acid. The $\mathrm{IC}_{50}$ were determined directly as a concentration of the ethanolic extract and then assuming that mostly such antioxidant activity may be due to the phenolic compounds it is the calculated as concentration of polyphenols in the extract. In addition to the determination of $\mathrm{IC}_{50}$, an optimization of the method was performed by determining the kinetic of DPPH reduction by our extracts. For $\mathrm{IC}_{50}$ results obtained with concentrations of extracts, the Tukey analysis on differences between estimated averages allowed us to distinguish between 6 groups significantly different $(\mathrm{p}<0.05)$ (Table 3$)$. Thus, antioxidant activity had decreased from the first group to the sixtieth. However, overlaps have been observed between groups sharing one or more species. The first group, consisting of antioxidant activity from 3 species extracts, had the highest antioxidant potential. They were $B$. longifolia $(0.13 \pm 0.00 \mathrm{mg}$ of extract $/ \mathrm{mL})>$ M. eminii $(5.583 \pm 1.67 \mathrm{mg}$ of extract $/ \mathrm{mL})>$ E. abyssinica $(5.89 \pm 0.6600 \mathrm{mg}$ of extract $/ \mathrm{mL})$ and no significant differences $(\mathrm{p}>0.05)$ were observed between them. These three species showed antioxidant capacity comparable to that of ascorbic acid. The next group that showed high antioxidant activity was composed of species sharing the letter « $\mathrm{d} »$. They were no significantly different at $\mathrm{p}>0.05$; order being M. eminii $>$ E. abyssinica $>T$. vogaelii $>M$. arboreus. Oilcake extracts from (P. curatellifolia and S. tragacantha) were unable to reduce $50 \%$ of DPPH. With maximum concentration, $P$. curatellifolia and $S$. tragacantha had reduced $31.45 \pm 3.33$ and $46.09 \pm 3.54 \%$ of $\mathrm{DPPH}$, respectively. However, compared to ascorbic acid, the antioxidant activity of all extracts were generally promising. This was revealed very well when expressing $\mathrm{IC}_{50}$ as a concentration of polyphenols in the extract.

The application of Tukey test on $\mathrm{IC}_{50}$ calculated related to the polyphenol concentrations divided the results into 5 groups significantly different at $\mathrm{p}<0.05$ (Table 3 ). The first powerful group for antioxidant activity was constituted by B. longifolia $(0.005 \pm 0.00 \mathrm{mg} \mathrm{GAE} / \mathrm{mL})$ extract slightly higher $(\mathrm{p}<0.05)$ than that of ascorbic acid. The first group was followed by that of 5 species whose averages did not differ significantly $(\mathrm{p}>0.05)$ from that of ascorbic acid and order is as: M. eminii $>U$. angolensis $>$ E. abyssinica $>$ I. involucrata $>$ M. arboreus. This suggested that the purification of the extracts will lead to a promising bioactive molecules that could at least be effective as the standard.

Table 3. Antioxidant activity of seed oilcake extracts with DPPH assay: $\mathrm{TIC}_{50}, \mathrm{IC}_{50}$ expressed as $\mathrm{mg} \mathrm{GAE} / \mathrm{mL}$ was calculated relative to the total polyphenol, $\mathrm{IC}_{50}$ expressed as $\mathrm{mg} / \mathrm{mL}$ was determined in crude extract, EA calculated relative to the concentration of crude extract.

\begin{tabular}{|c|c|c|c|c|}
\hline \multirow{2}{*}{ Plant species } & $\mathrm{IC}_{50}(\mathrm{TPhC})$ & $\mathrm{IC}_{50}$ (extracts) & $\mathrm{TIC}_{50}$ & EA \\
\hline & mg GAE/mL & $\mathrm{mg} / \mathrm{mL}$ & $\min$ & $\mathrm{mL} / \mu \mathrm{g} . \mathrm{mm}$ \\
\hline P. curatellifolia & - & - & - & - \\
\hline M. arboreus & $0.32 \pm 0.02^{\mathrm{cd}}$ & $10.99 \pm 0.75^{\mathrm{cde}}$ & $35.55 \pm 0.13 b$ & $2.41 \pm 0.84^{\mathrm{c}}$ \\
\hline M. eminii & $0.24 \pm 0.14^{\mathrm{cd}}$ & $5.583 \pm 1.67^{\mathrm{ef}}$ & $27.77 \pm 0.22^{\mathrm{c}}$ & $5.10 \pm 0.54^{c}$ \\
\hline S. tragacantha & - & - & - & - \\
\hline A.senegalensis & $0.58 \pm 0.14^{\mathrm{ab}}$ & $18.45 \pm 4.35^{\mathrm{b}}$ & $26.11 \pm 0.12^{\mathrm{c}}$ & $1.53 \pm 0.46^{\mathrm{c}}$ \\
\hline U. angolensis & $0.25 \pm 0.02^{\mathrm{cd}}$ & $17.27 \pm 1.29^{\mathrm{bc}}$ & $20.83 \pm 0.07^{d}$ & $1.30 \pm 0.27^{\mathrm{c}}$ \\
\hline C.decapitala & $0.43 \pm 0.10^{\mathrm{bc}}$ & $65.56 \pm 8.38^{\mathrm{a}}$ & $30.55 \pm 0.15^{\mathrm{c}}$ & $0.46 \pm 0.01^{\mathrm{c}}$ \\
\hline D. viscosa & $0.37 \pm 0.13^{\mathrm{bc}}$ & $19.47 \pm 0.76^{\mathrm{b}}$ & $51.66 \pm 0.33^{\mathrm{a}}$ & $2.65 \pm 0.12^{\mathrm{c}}$ \\
\hline E. abyssinica & $0.27 \pm 0.17^{\mathrm{cd}}$ & $5.89 \pm 0.66^{\mathrm{ef}}$ & $13.89 \pm 0.05^{\mathrm{e}}$ & $1.97 \pm 0.45^{\mathrm{c}}$ \\
\hline I. involucrata & $0.29 \pm 0.03^{\mathrm{cd}}$ & $13.82 \pm 0.99^{\mathrm{bcd}}$ & $34.99 \pm 0.16^{\mathrm{b}}$ & $2.54 \pm 0.06^{\mathrm{c}}$ \\
\hline T. vogaelii & $0.67 \pm 0.18^{\mathrm{a}}$ & $7.99 \pm 0.80^{\text {de }}$ & $51.66 \pm 0.33^{\mathrm{a}}$ & $6.54 \pm 0.74^{\mathrm{c}}$ \\
\hline B. longifolia & $0.005 \pm 0.00^{\mathrm{e}}$ & $0.13 \pm 0.00^{f}$ & $15.55 \pm 0.08^{\mathrm{e}}$ & $163.06 \pm 26.29^{a}$ \\
\hline Ascorbic acid & $0.09 \pm 0.00^{\mathrm{de}}$ & $0.09 \pm 0.00^{\mathrm{f}}$ & $5.00 \pm 0.02^{\mathrm{f}}$ & $52.63 \pm 1.58^{b}$ \\
\hline
\end{tabular}

Results are mean of three replicates with standard errors (Means \pm S.E, $n=3$ ). In each column, values with different letters mean that are significantly different $(p<0.05)$. 
Table 4. Pearson's correlation between, Oil content ethanolic extracts (Eth Extr), total sugar contents (TSC), total polyphenol

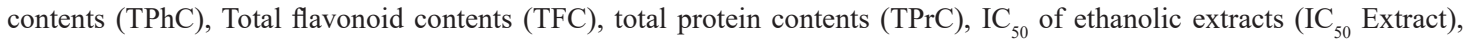
$\mathrm{IC}_{50}$ calculated based on total polyphenols $\left(\mathrm{IC}_{50} \mathrm{TPhP}\right)$, Ferric reducing antioxidant power (FRAP) assay, and effectiveness antiradical (EA).

\begin{tabular}{|c|c|c|c|c|c|c|c|c|c|c|}
\hline & $\begin{array}{c}\text { Oil } \\
\text { content }\end{array}$ & $\begin{array}{l}\text { Eth } \\
\text { Extr }\end{array}$ & TSC & TPhC & TFC & TPrC & FRAP & $\begin{array}{c}\mathrm{IC}_{50} \\
\text { Extract }\end{array}$ & $\begin{array}{c}\mathrm{IC}_{50} \\
\text { TPhP }\end{array}$ & EA \\
\hline Oil content & 1 & $-.342 *$ & $-.355^{*}$ & $-.529 * *$ & -.027 & -.006 & -.295 & -.258 & -.268 & $-.330 *$ \\
\hline Eth Extr & & 1 & $.409 *$ & .229 & -.216 & -.268 & .131 & $.477 * *$ & .235 & .184 \\
\hline TSC & & & 1 & $.536^{* *}$ & -.311 & $-.568 * *$ & $.782 * *$ & .210 & -.325 & $.781 * *$ \\
\hline $\mathrm{TPhC}$ & & & & 1 & -.042 & $-.371 *$ & $.712 * *$ & -.304 & -.037 & $.717 * *$ \\
\hline TFC & & & & & 1 & $.523 * *$ & -.198 & .184 & $.448 * *$ & -.239 \\
\hline $\mathrm{TPrC}$ & & & & & & 1 & $-.533 * *$ & $.341 *$ & $.599 * *$ & $-.577 * *$ \\
\hline FRAP & & & & & & & 1 & -.196 & -.305 & $.871 * *$ \\
\hline $\mathrm{IC}_{50}$ (Extrait) & & & & & & & & 1 & $.403 *$ & -.243 \\
\hline $\mathrm{IC}_{50}(\mathrm{TPhP})$ & & & & & & & & & 1 & $-.332 *$ \\
\hline EA & & & & & & & & & & 1 \\
\hline
\end{tabular}

*The correlation is significant at the 0.05 level (bilateral); **The correlation is significant at the 0.01 level (bilateral).

As mentioned in Table 3, steady states differ greatly from one species to another. With Tukey statistic, obtained group number reached to six with different species composition and different level of significance at $\mathrm{p}<0.05$. There was no overlap from one group to another. A complementarity between data from $\mathrm{IC}_{50}$ and $\mathrm{TIC}_{50}$ was observed. To reach steady state, species that had high antioxidant activity considering $\mathrm{IC}_{50}$ realized a shorter time relatively to those with low antioxidant activity. After the EA calculation by $\mathrm{IC}_{50}$ and $\mathrm{TIC}_{50}$ parameters, two groups (B. longifolia $>$ all other species) significant difference $(p<0.05)$ were obtained. This suggested that there was synergy of these two parameters for an estimate close to reality. Thus, with the exception of $B$. longifolia $(163.06 \pm 26.29 \mathrm{~mL} / \mu \mathrm{g} . \mathrm{mm})$, all species submitted to the Tukey test were found to have no significant difference $(\mathrm{p}>0.05)$ for antioxidant activity. Their values varied from 0.46 to $6.54 \mathrm{~mL} / \mu \mathrm{g} . \mathrm{mm}$.

\subsubsection{Ferric ions reducing activity}

Assessment of antioxidant potential in the extracts from different oilcakes was also carried out using the FRAP method. The results are shown in Table 2. Among the 6 groups forme, extracts of B. longifolia $(2618.21 \pm 161.22 \mathrm{mg} \mathrm{GAE} / 100 \mathrm{~g})$ were shown to be the much more powerful reducers of the ferric ions to ferrous ion. It was 22 times more reductive than that of the next specie. A similar value was reported in propolis extract (Mouhoubi-Tafinine et al., 2016). The following species (M. arboreus, A. senegalensis, C. decapitala and E. abyssinica) were, respectively, $115.31 \pm 4.06>110.31 \pm 6.90$ $>87.06 \pm 6.22>78.33 \pm 6.98 \mathrm{mg} \mathrm{GAE} / 100 \mathrm{~g}$ with no significant difference between them. As in the DPPH method, $P$. curatellifolia (16.813 mg GAE/100 g) and $S$. tragacantha (16.133 mg GAE/100 g) showed a very low reducing power of the ferric ions to ferrous ion. However, the last low content was that of I. involucrate $15.75 \pm 2.91 \mathrm{mg} \mathrm{GAE} / 100 \mathrm{~g}$.
The highest antioxidant power obtained in these species may be related to their high polyphenol contents (Figure 6A) and flavonoid (Figure 6B). Significant correlation $(\mathrm{p}<0.05)$ was observed between polyphenols content and antioxidant activity, on the one hand, and significant correlation $(p<0.05)$ between flavonoid contents and antioxidant activity, on the other hand (Table 4). Several studies reported positive correlation between $\mathrm{TPhC}$ and antioxidant activity (Hodzic et al., 2009; Zheng and Wang, 2001). Generally, free radical scavenging and antioxidant activity of phenolic (e.g. flavonoids, phenolic acids) mainly depends on the number and position of hydrogen-donating hydroxyl groups on the aromatic ring of the phenolic molecules, and is also affected by other factors, such as glycosylation of aglycones, other H-donating groups (-NH, -SH) (Cai et al., 2004). B. longifolia had a high $\mathrm{TPhC}$ and a powerful antioxidant activity nevertheless its TFC is low. In some species, the presence of large $\mathrm{TPhC}$ does not necessarily lead to the large TFC (Mouhoubi-Tafinine et al., 2016). The important antioxidant activity of $B$. longifolia is explained by the presence of other polyphenols than flavonoids. In addition to flavonoids, antioxidant also depends of phenolic acids (Nakatani, 2000; Rice-Evans et al., 1996; Zheng and Wang, 2001) and tannins, coumarins, lignans, quinones, stilbenes and curcuminoids (Cai et al., 2004).

\section{Conclusion}

It is for the first time that some potential oleaginous seeds from Burundi were studied. Our study highlighted the potential of some natural resources to be used as source of edible oil and valuable antioxidant compounds. Important oil contents were found in most plants studied through the five ecogeographic zones of the country. Six highest oil contents were ranged from 20 to $62 \%$. Oilcake obtained after oil extraction was found to contain significant protein contents that could be used in livestock feed. While synthetic antioxidant components are reported to be toxic 
(Houbairi et al., 2015; Rabeta and Nur Faraniza, 2013), our results suggested that most of species studied can be resource of natural bioactive molecules. Important $\mathrm{TPhC}$ were observed in 8 species and were ranged from 229.061 to $1035.55 \mathrm{mg} \mathrm{GAE} / 100 \mathrm{~g}$ DM. Exceptional antioxidant activity was found in B. longifolia with $163.06 \pm 26.29 \mathrm{~mL} / \mu \mathrm{g} . \mathrm{min}$ in DPPH assay and with 2618.21 $\pm 161.22 \mathrm{GAE} / 100 \mathrm{~g}$ DM in FRAP assay. This makes it understandable that they contain bioactive molecules which, once isolated, could be useful in the agri-food, pharmaceutical and cosmetic fields. It may also be one of the sustainable ways to protect the environment since the exploited part of the plant is a seed and give rise to the domestication

\section{Acknowledgements}

The authors thank the Moroccan-Burundian cooperation for financing this work through a scholarship and the Burundian Office for Environmental Protection (OBPE) for facilitating access to its various parks and nature reserves.

\section{Supplementary Material}

Supplementary material accompanies this paper.

Supplementary Table 1: Local uses of E. abyssinica, A. senegalensis, B. longifolia, C. decapetala, D. viscosa, I. involucrata, M. arboreus, M. eminii, P. curatellifolia, $S$. tragacantha, T. vogelii, U. angolensis plant in Burundi This material is available as part of the online article from http://www.scielo.br/bjb.

\section{References}

ABASSE, T., WEBER, J.C., KATKORE, B., BOUREIMA, M., LARWANOU, M. and KALINGANIRE, A., 2011. Morphological variation in Balanites aegyptiaca fruits and seeds within and among parkland agroforests in eastern Niger. Agroforestry Systems, vol. 81, no. 1, pp. 57-66. http://dx.doi.org/10.1007/s10457-010-9323-x.

ABBO, S. and GOPHER, A., 2017. Near eastern plant domestication: a history of thought. Trends in Plant Science, vol. 22, no. 6, pp. 491-511. http://dx.doi.org/10.1016/j.tplants.2017.03.010. PMid:28434795.

ACHTEN, W.M.J., VERCHOT, L., FRANKEN, Y.J., MATHIJS, E., SINGH, V.P., AERTS, R. and MUYS, B., 2008. Jatropha biodiesel production and use. Biomass and Bioenergy, vol. 32, no. 12, pp. 1063-1084. http://dx.doi.org/10.1016/j.biombioe.2008.03.003.

ALJADI, A.M. and KAMARUDDIN, M.Y., 2004. Evaluation of the phenolic contents and antioxidant capacities of two Malaysian floral honeys. Food Chemistry, vol. 85, no. 4, pp. 513-518. http:// dx.doi.org/10.1016/S0308-8146(02)00596-4.

AMARI, N.O., BOUZOUINA, M., BERKANI, A. and LOTMANI, B., 2014. Phytochemical screening and antioxidant capacity of the aerial parts of Thymelaea hirsuta L. Asian Pacific Journal of Tropical Disease, vol. 4, no. 2, pp. 104-109. http:// dx.doi.org/10.1016/S2222-1808(14)60324-8.

AMEZOUAR, F., BADRI, W., HSAINE, M., BOURHIM, N. and FOUGRACH, H., 2013. Antioxidant and anti-inflammatory activities of Moroccan Erica arborea L. Pathologie Biologie, vol. 61, no. 6, pp. 254-258. http://dx.doi.org/10.1016/j.patbio.2013.03.005. PMid:23647695.

BALASUNDRAM, N., SUNDRAM, K. and SAMMAN, S., 2006. Phenolic compounds in plants and agri-industrial byproducts: antioxidant activity, occurrence, and potential uses. Food Chemistry, vol. 99, no. 1, pp. 191-203. http://dx.doi.org/10.1016/j. foodchem.2005.07.042.

BARRERA-ARELLANO, D., BADAN-RIBEIRO, A.P. and SERNA-SALDIVAR, S.O., 2019. Corn oil: composition, processing, and utilization. In: S.O. SERNA-SALDIVAR, ed. Corn: chemistry and technology. 3rd ed. New York: Elsevier. http://dx.doi.org/10.1016/B978-0-12-811971-6.00021-8.

BEISSON, F., FERTÉ, N., BRULEY, S., VOULTOURY, R., VERGER, R. and ARONDEL, V., 2001. Oil-bodies as substrates for lipolytic enzymes. Biochimica et Biophysica Acta, vol. 1531, no. 1-2, pp. 47-58. http://dx.doi.org/10.1016/S1388-1981(01)00086-5.

BOSKOU, D. and MORTON, I.D., 1976. Effect of plant sterols on the rate of deterioration of heated oils. Journal of the Science of Food and Agriculture, vol. 27, no. 10, pp. 928-932. http:// dx.doi.org/10.1002/jsfa.2740271006

BOZDOGAN, D., ARSLAN, M. and OKSUZ, A., 2018. Saudi Journal of Biological Sciences Physicochemical properties of cold pressed sunflower, peanut, rapeseed, mustard and olive oils grown in the Eastern Mediterranean region. Saudi Journal of Biological Sciences, vol. 26. http://dx.doi.org/10.1016/j.sjbs.2018.04.005.

BRADFORD, M.M., 1976. A rapid and sensitive method for the quantitation of microgram quantities of protein utilizing the principle of protein-dye binding. Analytical Biochemistry, vol. 72, no. 1-2, pp. 248-254. http://dx.doi.org/10.1016/00032697(76)90527-3. PMid:942051.

BRIGHENTI, F., VALTUEÑA, S., PELLEGRINI, N., ARDIGÒ, D., DEL RIO, D., SALVATORE, S., PIATTI, P., SERAFINI, M. and ZAVARONI, I., 2005. Total antioxidant capacity of the diet is inversely and independently related to plasma concentration of high-sensitivity C-reactive protein in adult Italian subjects. British Journal of Nutrition, vol. 93, no. 5, pp. 619-625. http:// dx.doi.org/10.1079/BJN20051400. PMid:15975160.

CAI, Y., LUO, Q., SUN, M. and CORKE, H., 2004. Antioxidant activity and phenolic compounds of 112 traditional Chinese medicinal plants associated with anticancer. Life Sciences, vol. 74, no. 17, pp. 2157-2184. http://dx.doi.org/10.1016/j.1fs.2003.09.047. PMid:14969719.

CHAN, K.W., KHONG, N.M.H., IQBAL, S., MANSOR, S.M. and ISMAIL, M., 2013. Defatted kenaf seed meal (DKSM): prospective edible flour from agricultural waste with high antioxidant activity. Lebensmittel-Wissenschaft + Technologie, vol. 53, no. 1, pp. 308-313. http://dx.doi.org/10.1016/j.lwt.2013.01.003.

CHANIOTI, S. and TZIA, C., 2017. Optimization of ultrasoundassisted extraction of oil from olive pomace using response surface technology: oil recovery, unsaponifiable matter, total phenol content and antioxidant activity. Lebensmittel-Wissenschaft + Technologie, vol. 79, pp. 178-189. http://dx.doi.org/10.1016/j. lwt.2017.01.029.

CHOE, E. and MIN, D.B., 2009. Mechanisms of antioxidants in the oxidation of foods. Comprehensive Reviews in Food Science and Food Safety, vol. 8, no. 4, pp. 345-358. http://dx.doi. org/10.1111/j.1541-4337.2009.00085.x.

CONNOR, A.M., LUBY, J.J., TONG, C.B.S., FINN, C.E. and HANCOCK, J.F., 2002. Genotypic and environmental variation 
in antioxidant activity, total phenolic content, and anthocyanin content among blueberry cultivars. Acta Horticulturae, no. 574, pp. 209-213. http://dx.doi.org/10.17660/ActaHortic.2002.574.31.

COUTINHO, I.D., HENNING, L.M.M., DÖPP, S.A., NEPOMUCENO, A., MORAES, L.A.C., MARCOLINOGOMES, J., RICHTER, C., SCHWALBE, H. and COLNAGO, L., 2018. Data in Brief Identi fi cation of primary and secondary metabolites and transcriptome pro fi le of soybean tissues during different stages of hypoxia. Data in Brief, vol. 21, pp. 1089-1100. http://dx.doi.org/10.1016/j.dib.2018.09.122. PMid:30450404.

CUVELIER, M. and MAILLARD, M.-N., 2012. Stabilité des huiles alimentaires au cours de leur stockage. $O C L$, vol. 19, no. 2, pp. 125-132. http://dx.doi.org/10.1051/ocl.2012.0440.

DOBLADO-MALDONADO, A.F., PIKE, O.A., SWELEY, J.C. and ROSE, D.J., 2012. Key issues and challenges in whole wheat fl our milling and storage. Journal of Cereal Science, vol. 56, no. 2, pp. 119-126. http://dx.doi.org/10.1016/j.jcs.2012.02.015.

DUBOIS, M., GILLES, K.A., HAMILTON, J.K., REBERS, P.A. and SMITH, F., 1956. Colorimetric method for determination of sugars and related substances. Analytical Chemistry, vol. 28, no. 3, pp. 350-356. http://dx.doi.org/10.1021/ac60111a017.

EL HACHIMI, F., EL ANTARI, A., BOUJNAH, M., BENDRISSE, A. and ALFAIZ, C., 2015. Comparison of oils seed and fatty acid content of various Moroccan populations of jujube. Journal of Materials and Environmental Science, vol. 6, no. 5, pp. 1488-1502.

FÉVRIER, R., GASNIER, A. and VACHEL, J.P., 1952. Valeur alimentaire du tourteau de soja influencé du traitement thermique. Annales de Zootechnie, vol. 1, no. 4, pp. 11-32. http://dx.doi. org/10.1051/animres:19520402.

FOOD AND AGRICULTURE ORGANIZATION - FAO. World Health Organization - WHO, 2001a. Codex standard for olive oil, virgin and refined and for refined olive-pomace oil. In: FOOD AND AGRICULTURE ORGANIZATION - FAO. Codex Alimentarius. Rome: FAO.

FOOD AND AGRICULTURE ORGANIZATION - FAO. World Health Organization - WHO, 2001b. Codex standard for named vegetable oils. In: FOOD AND AGRICULTURE ORGANIZATION - FAO. Codex Alimentarius. Rome: FAO.

FOOD AND AGRICULTURE ORGANIZATION - FAO. World Health Organization - WHO, 2017. Committee on fats and session of the codex oils. Rome: FAO.

GAVEAU, D.L.A., WICH, S., EPTING, J., JUHN, D., KANNINEN, M. and LEADER-WILLIAMS, N., 2009. The future of forests and orangutans (Pongo abelii) in Sumatra: predicting impacts of oil palm plantations, road construction, and mechanisms for reducing carbon emissions from deforestation. Environmental Research Letters, vol. 4, no. 3, pp. 034013. http:// dx.doi.org/10.1088/1748-9326/4/3/034013.

GHASEMZADEH, A. and GHASEMZADEH, N., 2011. Flavonoids and phenolic acids: role and biochemical activity in plants and human. Journal of Medicinal Plants Research, vol. 5, no. 31, pp. 6697-6703. http://dx.doi.org/10.5897/JMPR11.1404.

HATAMNIA, A.A., ABBASPOUR, N. and DARVISHZADEH, R., 2014. Antioxidant activity and phenolic profile of different parts of Bene (Pistacia atlantica subsp. kurdica) fruits. Food Chemistry, vol. 145, pp. 306-311. http://dx.doi.org/10.1016/j. foodchem.2013.08.031. PMid:24128482.

HODZIC, Z., PASALIC, H., MEMISEVIC, A., SRABOVIC, M., SALETOVIC, M. and POLJAKOVIC, M., 2009. The influence of total phenols content on antioxidant capacity in the whole grain extracts. European Journal of Scientific Research, vol. 28, pp. 471-477. https://doi.org/https://doi.org/10.1.1.335.7023.

HOUBAIRI, S., ELMIZIANI, I., LAMIRI, A. and ESSAHLI, M., 2015. Comparison of the antioxidant activity of aromatic medicinal plants of Moroccan origin. European Journal of Medicinal Plants, vol. 10, no. 4, pp. 1-10. http://dx.doi.org/10.9734/ EJMP/2015/19928.

HUSSEIN, I.H., 2009. Chemical characterization of the seed and antioxidant activity of various parts of Salvadora persica. Journal of the American Oil Chemists 'Society, vol. 86, no. 9, pp. 857-865. http://dx.doi.org/10.1007/s11746-009-1422-3.

INTERNATIONAL ORGANIZATION FOR STANDARDIZATION - ISO, 2000. ISO 18609: animal and vegetable fats and oils: determination of unsaponifiable matter: method using hexane extraction. Geneva: ISO.

INTERNATIONAL ORGANIZATION FOR STANDARDIZATION - ISO, 2007. ISO 3960: animal and vegetable fats and oils: determination of peroxide value-Iodometric (visual) endpoint determination. Geneva: ISO.

INTERNATIONAL ORGANIZATION FOR STANDARDIZATION - ISO, 2009. ISO 660: animal and vegetable fats and oils: determination of acid value and acidity. Geneva: ISO.

JIA-XI, L., CHUN-XIA, Z., YING, H., MENG-HAN, Z., YA-NAN, W., YUE-XIN, Q., JING, Y., WEN-ZHI, Y., MIAOMIAO, J. and DE-AN, G., 2019. Application of multiple chemical and biological approaches for quality assessment of Carthamus tinctorius L. (safflower) by determining both the primary and secondary metabolites. Phytomedicine, vol. 58, pp. 152826. http:// dx.doi.org/10.1016/j.phymed.2019.152826. PMid:30836217.

JIN, L., ZHANG, Y., YAN, L., GUO, Y. and NIU, L., 2012. Phenolic compounds and antioxidant activity of bulb extracts of six Lilium Species native to China. Molecules (Basel, Switzerland), vol. 17, no. 8, pp. 9361-9378. http://dx.doi.org/10.3390/molecules17089361.

KHATTAB, R.Y. and ZEITOUN, M.A., 2013. Quality evaluation of flaxseed oil obtained by different extraction techniques. Lebensmittel-Wissenschaft + Technologie, vol. 53, no. 1, pp. 338-345. http://dx.doi.org/10.1016/j.lwt.2013.01.004.

KOH, L.P. and WILCOVE, D.S., 2008. Is oil palm agriculture really destroying tropical biodiversity? Conservation Letters, vol. 1, no. 2, pp. 60-64. http://dx.doi.org/10.1111/j.1755-263X.2008.00011.x.

KSOURI, R., MEGDICHE, W., FALLEH, H., TRABELSI, N., BOULAABA, M., SMAOUI, A. and ABDELLY, C., 2008. Influence of biological, environmental and technical factors on phenolic content and antioxidant activities of Tunisian halophytes. C. C. R. Biologies, vol. 331, no. 11, pp. 865-873. http://dx.doi. org/10.1016/j.crvi.2008.07.024. PMid:18940702.

KULKARNI, Y.A., GARUD, M.S., OZA, M.J., BARVE, K.H. and GAIKWAD, A.B., 2016. Diabetes, diabetic complications, and flavonoids. In: R.R. WATSON and V.R. PREEDY, eds. Fruits, vegetables, and herbs. Amsterdam: Elsevier. http://dx.doi. org/10.1016/B978-0-12-802972-5.00005-6.

LOPES-LUTZ, D., ALVIANO, D.S., ALVIANO, C.S. and KOLODZIEJCZYK, P.P., 2008. Screening of chemical composition, antimicrobial and antioxidant activities of Artemisia essential oils. Phytochemistry, vol. 69, no. 8, pp. 1732-1738. http://dx.doi. org/10.1016/j.phytochem.2008.02.014. PMid:18417176.

MADZIMURE, J., MUSIMURIMWA, C., CHIVANDI, E., GWIRIRI, L. and MAMHARE, E., 2011. Milk yield and quality in 
Guernsey cows fed cottonseed cake-based diets partially substituted with baobab (Adansonia digitata L.) seed cake. Tropical Animal Health and Production, vol. 43, no. 1, pp. 77-82. http://dx.doi. org/10.1007/s11250-010-9656-5.

MALECKA, M., 1994. The effect of squalene on the thermostability of rapeseed oil. Food, vol. 38, pp. 135-140.

MARIOD, A. and MATTHÄUS, B., 2007. Fatty acids, tocopherols, sterols, phenolic profiles and oxidative stability of cucumis melo var. agrestis oil. Journal of Food Lipids, vol. 15, no. 1, pp. 56-67. http://dx.doi.org/10.1111/j.1745-4522.2007.00102.x.

MEEATU. Ministère de l'Eau, de l'Environnement, de l'Aménagement du T. et de l'Urbanisme - MEEATU, 2013. Plan stratégique de développement et de renforcement des capacités dans le domaine de la biodiversité 2013-2020. Bujumbura, 55 p.

MERRIEN, A., CARRE, P. and QUINSAC, A., 2012. Des ressources oléagineuses variées potentiellement au service du développement de la chimie verte. Oléagineux Corps Gras Lipides, vol. 19, no. 1, pp. 6-9. http://dx.doi.org/10.1051/ocl.2012.0425.

MINAGRIE. Ministère de 1'Agricuture et de l'élevage MINAGRIE, 2008. Stratégie agricole nationale 2008-2015. Burundi, Bujumbura, $27 \mathrm{p}$.

MOUHOUBI-TAFININE, Z., OUCHEMOUKH, S. and TAMENDJARI, A., 2016. Antioxydant activity of some algerian honey and propolis. Industrial Crops and Products, vol. 88, pp. 85-90. http://dx.doi.org/10.1016/j.indcrop.2016.02.033.

NÁJERA, A.I., BUSTAMANTE, M.A., ALBisU, M., VALDIVIELSO, I., AMORES, G., MANDALUNIZ, N., ARRANZ, J., BARRON, L.J.R. and DE RENOBALES, M., 2017. Fatty acids, vitamins and cholesterol content, and sensory properties of cheese made with milk from sheep fed rapeseed oilcake. Journal of Dairy Science, vol. 100, no. 9, pp. 1-10. http:// dx.doi.org/10.3168/jds.2017-12588. PMid:28734602.

NAKATANI, N., 2000. Phenolic antioxidants from herbs and spices. BioFactors, vol. 13, no. 1-4, pp. 141-146. http://dx.doi. org/10.1002/biof.5520130123. PMid:11237173.

NGIYE, É., 2017. La filière palmier à huile au Burundi: acteurs et territoires. Toulouse: Université Toulouse.

OUHAMMOU, M., LAHNINE, L., MGHAZLI, S. and HIDAR, N., 2017. Valorisation of cellulosic waste basic cactus to prepare activated carbon. Journal of the Saudi Society of Agricultural Sciences, vol. 18, no. 2, pp. 133-140. http://dx.doi.org/10.1016/j. jssas.2017.03.003

PATRO, B.S., BAURI, A.K., MISHRA, S. and CHATTOPADHYAY, S., 2005. Antioxidant activity of myristica malabarica extracts and their constituents. Journal of Agricultural and Food Chemistry, vol. 53, no. 17, pp. 6912-6918. http://dx.doi.org/10.1021/jf050861x. PMid: 16104820

PAZHOUHANMEHR, S., FARHOOSH, R., SHARIF, A. and ESMAEILZADEH KENARI, R., 2016. Oxidation kinetics of common Kilka (Clupeonella cultiventris caspia) oil in presence of bene oils ' unsaponifiable matter. Food Chemistry, vol. 190, pp. 748-754. http://dx.doi.org/10.1016/j.foodchem.2015.05.100. PMid:26213034

POPOVICI, C., SAYKOVA, I. and TYLKOWSKI, B., 2009. Evaluation de l'activité antioxydant des composés phénoliques par la réactivité avec le radical libre DPPH. Revue de Génie Industriel, vol. 4, pp. 25-39.
PORTUGAL, A.C.X., LUCENA, L.C.F.L., LUCENA, A.E.F.L., COSTA, D.B. and LIMA, K.A., 2017. Rheological properties of asphalt binders prepared with maize oil. Construction \& Building Materials, vol. 152, pp. 1015-1026. http://dx.doi.org/10.1016/j. conbuildmat.2017.07.077.

RABETA, M.S. and NUR FARANIZA, R., 2013. Total phenolic content and ferric reducing antioxidant power of the leaves and fruits of garcinia atrovirdis and cynometra cauliflora. International Food Research Journal, vol. 20, pp. 1691-1696.

RIBEIRO, R.D.X., MEDEIROS, A.N., OLIVEIRA, R.L., ARAÚJO, G.G.L., QUEIROGA, R.D.C.E., RIBEIRO, M.D., SILVA, T.M., BEZERRA, L.R. and OLIVEIRA, R.L., 2018. Palm kernel cake from the biodiesel industry in goat kid diets. Part 2: physicochemical composition, fatty acid profile and sensory attributes of meat. Small Ruminant Research, vol. 165, pp. 1-7. http://dx.doi.org/10.1016/j.smallrumres.2018.05.014

RICE-EVANS, C.A., MILLER, N.J. and PAGANGA, G., 1996. Structure-antioxidant activity relationships of flavonoids and phenolic acids. Free Radical Biology \& Medicine, vol. 20, no. 7, pp. 933-956. http://dx.doi.org/10.1016/0891-5849(95)02227-9. PMid:8743980.

SALGADO, P.R., DRAGO, S.R., MOLINA ORTIZ, S.E., PETRUCCELLI, S., ANDRICH, O., GONZÁLEZ, R.J. and MAURI, A.N., 2012. Production and characterization of sunflower (Helianthus annuus L.) protein-enriched products obtained at pilot plant scale. Lebensmittel-Wissenschaft + Technologie, vol. 45, no. 1, pp. 65-72. http://dx.doi.org/10.1016/j.lwt.2011.07.021.

SÁNCHEZ-MORENO, C., LARRAURI, J.A. and SAURACALIXTO, F., 1998. A procedure to measure the antiradical efficiency of polyphenols. Journal of the Science of Food and Agriculture, vol. 76, no. 2, pp. 270-276. http://dx.doi.org/10.1002/ (SICI)1097-0010(199802)76:2<270::AID-JSFA945>3.0.CO;2-9.

SANTIAGO, E., DOMÍNGUEZ-FERNÁNDEZ, M., CID, C. and DE PEÑA, M., 2017. Impact of cooking process on nutritional composition and antioxidants of cactus cladodes (Opuntia ficusindica). Food Chemistry, vol. 240, pp. 1055-1062. http://dx.doi. org/10.1016/j.foodchem.2017.08.039. PMid:28946223.

SATHIVEL, S., HUANG, J. and PRINYAWIWATKUL, W., 2008. Thermal properties and applications of the Arrhenius equation for evaluating viscosity and oxidation rates of unrefined pollock oil. Journal of Food Engineering, vol. 84, no. 2, pp. 187-193. http://dx.doi.org/10.1016/j.jfoodeng.2007.04.027.

SCHRÖDER, M. and VETTER, W., 2012. Investigation of unsaponifiable matter of plant oils and isolation of eight phytosterols by means of high-speed counter-current chromatography. Journal of Chromatography A, vol. 1237, pp. 96-105. http://dx.doi. org/10.1016/j.chroma.2012.03.033. PMid:22481107.

SENEVIRATNE, K. and DISSANAYAKE, D.M.S., 2015. Effect of method of extraction on the quality of coconut oil. Journal of Science of the University of Kelaniya Sri Lanka, vol. 2, no. 0, pp. 63-72. http://dx.doi.org/10.4038/josuk.v2i0.2746.

SHAHIDI, F. and AMBIGAIPALAN, P., 2015. Phenolics and polyphenolics in foods, beverages and spices: antioxidant activity and health effects: a review. Journal of Functional Foods, vol. 18, pp. 820-897. http://dx.doi.org/10.1016/j.jff.2015.06.018.

SLINKARD, K. and SINGLETON, V.L., 1977. Total phenol analysis: automation and comparison with manual methods. American Journal of Enology and Viticulture, vol. 28, pp. 49-55. 
SONG, J., LI, Z., LIU, Z., GUO, Y. and QIU, L., 2017. Nextgeneration sequencing from bulked-segregant analysis accelerates the simultaneous identification of two qualitative genes in soybean. Frontiers of Plant Science, vol. 8, pp. 1-11. http://dx.doi. org/10.3389/fpls.2017.00919. PMid:28620406.

STAHL, E., SCHUETZ, E. and MANGOLD, H.K., 1980. Extraction of seed oils with liquid and supercritical carbon dioxide. Journal of Agricultural and Food Chemistry, vol. 28, no. 6, pp. 1153-1157. http://dx.doi.org/10.1021/jf60232a023.

SUN, H., MAO, X., WU, T., REN, Y., CHEN, F. and LIU, B., 2018. Novel insight of carotenoid and lipid biosynthesis and their roles in storage carbon metabolism in Chlamydomonas reinhardtii. Bioresource Technology, vol. 263, pp. 450-457. http://dx.doi. org/10.1016/j.biortech.2018.05.035. PMid:29772507.

TAN, C.P., MAN, Y.B.C., SELAMAT, J. and YUSOFF, M.S.A., 2002. Comparative studies of oxidative stability of edible oils by differential scanning calorimetry and oxidative stability index methods. Food Chemistry, vol. 76, no. 3, pp. 385-389. http:// dx.doi.org/10.1016/S0308-8146(01)00272-2.

THOBANI, M. and DIOSADY, L.L., 1997. Two-phase solvent extraction of canola. Journal of the American Oil Chemists Society, vol. 74, no. 3, pp. 207-214. http://dx.doi.org/10.1007/ s11746-997-0125-x.

ZHENG, W. and WANG, S.Y., 2001. Antioxidant activity and phenolic compounds in selected herbs. Journal of Agricultural and Food Chemistry, vol. 49, no. 11, pp. 5165-5170. http://dx.doi. org/10.1021/jf010697n.

ZOTTE, A.D., BRAND, T.S., HOFFMAN, L.C., SCHOON, K., CULLERE, M. and SWART, R., 2013. Effect of cottonseed oilcake inclusion on ostrich growth performance and meat chemical composition. Meat Science, vol. 93, no. 2, pp. 194-200. http:// dx.doi.org/10.1016/j.meatsci.2012.08.027. PMid:22998999. 